Seventh: That the paralytic or non-paralytic character of a hyperphoria can be determined with much greater ease and certainty after than before the test.

Eighth: That the theory held by some that the lateral deviations are secondary to the vertical receives no support from this test so far as exophoria is concerned. If the latter were due to efforts to overcome hyperphoria, it would diminish when these efforts cease, as during an occlusion test. But this is contrary to the facts. It usually increases. In some cases of esophoria, however, the convergence diminishes, disappears, or is converted into divergence co-incidentally with increase in the degree or change in the form of hyperphoria.

\title{
A - DISCUSSION UPON THE ILLUMINATION OF MINES, WITH PARTICULAR REFERENCE TO MINERS' NYSTAGMUS*
}

The Chairman (Mr. J. Herbert Parsons) : I do not think I need introduce to you, who are interested in this subject, Dr. Lister Llewellyn. It was an extremely fortunate event when he was chosen first Tyndall Scholar, and he has very fully justified his election. He has produced an enormous amount of evidence in support of the view that the essential cause of miners' nystagmus is deficient illumination, and, at least in the opinion of most of us, he has thoroughly established that view.

Without further preamble, therefore, I will call upon Dr. Lister Llewellyn to read his paper.

\section{a-LIGHTING CONDITIONS IN MINES WITH SPECIAL REFERENCE TO THE EYESIGHT OF MINERS BY}

T. Lister Llewellyn, M.D., B.S. ASSISTANT PHYSICIAN, NORTH STAFFORDSHIRE INFIRMARY

\section{Synopsis of Contents}

I. Lighting conditions in mines-

General remarks.

Photometric measurements.

II. Physiological considerations of the effects of dull illumination on the eye.

III. The effect of dull illumination on the eyesight of minersInjury.

Disease.

*This discussion took place at a meeting of the Illuminating Engineering Society, on February 24,1920 , and is now published by kind permission of that Society. 
IV. Economic factors-

(1) Benefits to be expected-

Diminished incidence of accident and disease.

Increased output.

(2) Cost of increased illumination.

(3) Results obtained by increased illumination,

V. Standard of illumination required-

Comparison between candle and safety lamp.

The miners' lamp. .

Conclusion.

\section{Lighting Conditions in Mines}

The problem of illumination in the coal mine is complicated by the presence of fire damp, by the rough usage which the lamp selected receives at the hands of the collier, and by damage due to falls of roof and coal. The presence of fire damp will necessitate the retention, at any rate for many years, of the oil safety lamp for testing purposes. The hard usage the lamp gets makes its substantial construction necessary, and the need for protection against falls most unfortunately cuts off all rays directed upwards.

As I have stated in my lecture $\left(^{(}\right)$before the North Staffordshire Branch of the Institute of Mining Engineers the illumination in a coal mine depends on four factors:

(1) The candlepower of the source of light used.

(2) The distance at which this light has to be placed from the working area.

(3) The surface brightness of the surroundings.

(4) The composition of air in the workings.

(1) Candlepower of source of light used.-It seems incredible, but the source of light which gives the highest candlepower at the coal face is the tallow candle! By carefully spreading out the wick two candlepower may be obtained.

If measurements are taken at the coal face the modern oil safety lamp, with the exception of such lamps as the Hailwood combustion lamp, rarely gives one-half candlepower. I do not say that they will not give more, but up to 1914 I had not obtained a higher reading. The modern electric lamp in use gives about one candlepower for eight hours. I have lately seen oil and electric lamps giving two to three candlepower, but they are not yet in use. Measurements of the latest lamps in use will be given below.

(2) In the safety lamp pit the lamp has to be placed at least two feet away from the swing of the pick. The lamp is often hung on a post and there is a tendency on the part of the miner to leave the lamp fixed. The law of inverse squares and the cosine law come very powerfully into operation. 
(3) The brightness of the surroundings. -The collier works in surroundings which are either coal or covered with coal dust. Almost all the incident light is absorbed and there is no colour relief.

Coal and coal dust absorb from $86-97$ per cent. of all incident light.

(4) Composition of air in the workings.-The light of an oil safety lamp diminishes rapidly when the oxygen percentage of the air falls, and the presence of moisture has the same effect. A tested oil lamp actually lost 60 per cent. of its candlepower in a poorly ventilated pit. The presence of dust, quite apart from the fouling of the lamp, also diminishes the illumination obtained.

Actual measurements at the coal face.- Up to 1914, as a result of a large number of observations in sèveral coal mines the average illumination at the coal face in a safety lamp pit was found to be 0.018 foot-candle; in candle pits the average illumination was 0.09 foot-candle. The readings are given in detail in my book. $\left.{ }^{2}\right)$

Through the help of Mr. Turner, of the Stafford Coal and Iron Company, I am able to give you measurements with the latest lamps in use.

The measurements given were all taken under the most favourable circumstances as a length of coal face had been cleared for the purpose. There was no dust, and all the lamps were fresh and clean, and in the case of the electric lamps, freshly charged. Six lamps of each of the five varieties mentioned below were used. The lamps were hung on the same nails and the coal face was marked with chalk to insure that the readings would be taken at the same place. The lamps were tested in the order given. The lamps were placed on the assumption that four holers and two loaders were working in the drift. The readings from one of the loaders' lamps give the average general illumination at the coal face, the readings from the holers' lamps give the illumination on the area actually being holed. Owing to the favourable conditions the figures are higher than they would be in actual practice. The average candle-

\begin{tabular}{|c|c|c|c|c|}
\hline . & & $\begin{array}{l}\text { Candle- } \\
\text { power. }\end{array}$ & $\begin{array}{l}\text { General } \\
\text { illumination } \\
\text { at coal face } \\
\text { in foot-candles. }\end{array}$ & $\begin{array}{c}\text { Illumination } \\
\text { on actual } \\
\text { working area } \\
\text { in foot-candles. }\end{array}$ \\
\hline 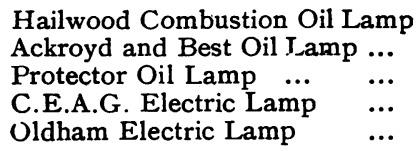 & $\begin{array}{l}\cdots \\
\cdots \\
\cdots \\
\cdots\end{array}$ & $\begin{array}{l}0.99 \\
0.58 \\
0.79 \\
0.96 \\
1.12\end{array}$ & $\begin{array}{l}0.017^{*} \\
0.021 \\
0.019 \\
0.032 \\
0.045\end{array}$ & $\begin{array}{l}0.075 \\
0.06 \\
0.06 \\
0.104 \\
0.113\end{array}$ \\
\hline
\end{tabular}


power of the lamps is also given. One C.E.A.G. lamp gave the best light -1.4 candle-power, but the general average of the Oldham lamp was higher. It is interesting to note that the illumination at the coal face given by the oil lamps does not compare favourably with the candle-power of the lamp. This is partly accounted for by the greater extent of the shadows thrown by the lamp standards.

These readings should be compared with others taken recently in another pit.

Colliers top holing in a dusty seam at end of shift :

Two C.E.A.G. electric lamps, average candlepower, 0.62 .

Illumination on area worked in foot-candles, 0:03.

Colliers getting coal in same seam, end of shift :

One C.E.A.G. electric lamp, candlepower, 0.8.

One Clanny oil lamp, candlepower, 0.36 .

Lamps over 8 feet away from the coal face, illumination at coal face less than 0.01 foot-candle.

Miscellaneous readings-

Well-lit pit bottom. Half-watt electric lamps :

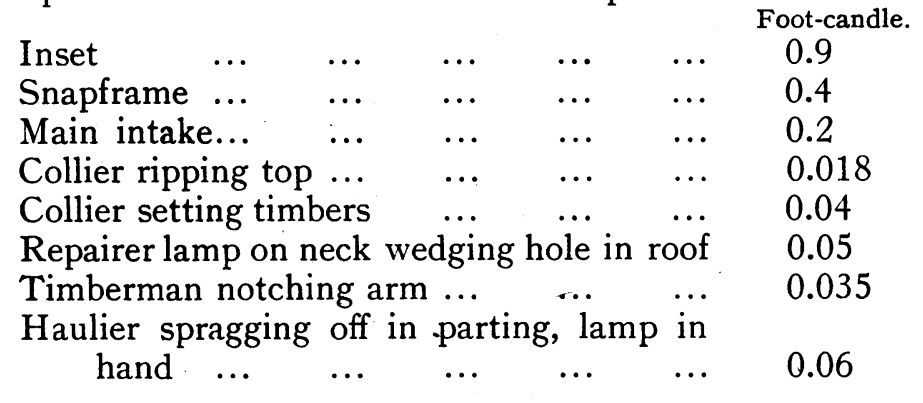

\section{II.-Physiological Considerations}

The effect of feeble illumination on the eye has always been of great interest to physiologists. Parsons $\left(^{3}\right)$ in his paper on "Scotopia or Vision in Dull Illumination" discusses this question fully. With the exception of the manufacture and packing of some specially sensitive photographic plates in darkness no industry is carried out in such feeble illumination as that of coal mining. Let us take some of the signs and symptoms of miners' nystagmus and see if they throw any light on the problem of vision in dull illumination.

Loss of sight.-One of the commonest and often the first symptoms is loss of sight, especially marked at night time or in the early morning, that is in feeble light. Men with normal refraction are often unable to read more than $6 / 36$ in the acute stages of the attack. Of 1,121 cases of miners' nystagmus only 103 could read 6/6. I have always looked upon an increase in visual acuity as a favourable prognostic sign. Cridland $\left({ }^{4}\right)$ describes contraction of the 
fields of vision for colour in the acute stages of the disease and a return to normal in convalescence.

Intolerance of bright light.-This symptom is often very marked. In miners' nystagmus, then, both extremes, bright illumination and dull illumination, cause trouble. In the normal person the eye can adapt itself within very wide limits of intensity. In miners' nystagmus the range is limited and there is a special failure of adaptation in feeble illumination. Stassen $\left(^{5}\right)$ lays stress on the sudden changes from light to darkness and from darkness to light. In my book (page 114) I say: "Failure of dark adaptation may quite well be the ultimate cause of miners' nystagmus."

Oscillation of the eyes.-Is this characteristic sign of the disease due to imperfect fixation or to fatigue of the oculo-motor centres ? In disordered action of the heart, so commonly found in soldiers, and in respiratory trouble due to poison gas, there is a neurasthenia of the regulating mechanism in the central nervous system. In both of these conditions fatigue is readily induced, and brings about results quite out of proportion to the increased work done. Does working in a dull illumination set up a corresponding fatigue ?

Is the ocular movement due to imperfect fixation?

The perifoveal region of the retina is more sensitive than the foveal for dull illumination. For accurate fixation in good light the object is brought to a focus on the fovea, a definitely circumscribed and specially sensitive area of the retina. If the perifoveal area is used one point is as good as another, and an area of equally sensitive points could be found in a circle, say ten degrees from the fovea. The object may be focussed on any one of these points or on one point after another. If so, a tendency to a circular or wheel-like motion of the eye might be set up, and it is a wheel-like movement which is the typical form of oscillation found in miners' nystagmus. Lancaster ${ }^{10}$ says that work in deficient light demands an amount of fixation greatly in excess of that called for under ordinary circumstances. Edridge-Green ${ }^{6}$ says that the movement of the eyes is in the interests of vision.

Tilting of head.- The backward inclination of the head, which is a most characteristic sign of the disease, is, in my opinion, the result of an attempt to get the eyes in a position of maximum stability, i.e., convergence and depression, and at the same time to direct the line of vision forward.

Colour relief.-What is the bearing of absence of contrast or colour relief ? Is Elworthy ${ }^{7}$ right when he lays the greatest stress on the lack of colour relief, or are light absorption and feebleness of illumination the chief factors?

Seasonal prevalence.-Why, as Dransart, ${ }^{8}$ Elworthy, ${ }^{7} \mathrm{Ohm}^{9}$, and myself ${ }^{2}$ have pointed out, should nystagmus be more common in the winter months? Ohm accepts my explanation that in winter 
the absence of sunlight (coal workers in the old days rarely saw the sun except on Sundays) interferes with the normal formation of pigment in the retinal cells. Stassen ${ }^{5}$ says that nystagmus is commoner among men working by day. Think of the colourless plant striving to grow in the cellar and of the nystagmus of albinoes. I think also that miners' nystagmus is commoner in men with fair hair and light coloured eyes.

Glare.-Although glare is generally associated with light of great intensity, in the low illumination of a coal mine any direct rays of light which fall into the eye produce inconvenience, amounting, in the case of the nystagmic worker, to discomfort or even pain. Many colliers also work in a reclining position, with the lamp at their feet, so that the light shines obliquely into their eyes. It is known that the effect of glare is increased when the source of light has a black background, and diminished when a white reflector is used. Very few colliers will work at the coal face with a reflector, as the amount of working area illuminated is too small, necessitating frequent changes in the position of the lamp. Mr. Turner, of the Stafford Company, gave a man working on a coal cutter a bull's eye miners' rescue lamp. The man refused to use the lamp after the first day, his reason being that he had to keep changing the position of the lamp continually. Would it be possible, however, by the use of a very large reflector with a matt surface, to give a diffused light over a comparatively large area, and so avoid glare ?

Quality of light.-It has been suggested by Nicholls that the eye has developed itself to be most sensitive to yellow light (Quoted by Trotter "Illumination," page 173). Given equal candlepower, up to five candlepower, are the yellow rays of the candle or oil lamp more restful to the eyes than the "hard" white electric light ? What would be the effect on candlepower of a coloured screen in front of an electric lamp? Men suffering from miners' nystagmus have complained of the glare of the electric lamp, but it is a well established fact that men, after failure with oil lamps, have been able to continue when given electric lamps. I do not think myself that the quéstion of hardness should be allowed to influence the more vital question of candlepower.

\section{III.-The Effect of Dull Illumination on the Eyesight of Miners}

(1) Injury.- - Miners, from the nature of their work, are very subject to injuries of the eye. In the same way as the tattooing of the skin by coal dust indicates his calling, so do the corneal scars, so frequently seen in old miners, tell of old injuries received. Although the injury to the eyes can only be indirectly attributed to bad illumination, the difficulty of attending promptly to the foreign body makes the prognosis in these cases bad, and loss of the eye frequently 
follows a comparatively trivial injury. In an investigation of the factors concerned in the causation of industrial accidents Dr. Vernon $\left({ }^{11}\right)$ found that accidents to the eye due to foreign bodies were from $7-27$ per cent. more numerous in the night than in the day. In 269 , or 18 per cent., of my cases there was a distinct connection between the history of an accident to the eye and the onset of nystagmus.

(2) Disease.-In my opinion, the dominating factor in the production of miners' nystagmus is the low illumination found both in the open light and 'safety lamp coal mine. The arguments in favour of this contention are given at length in my book before referred to.

Ohm says: Wherever the Wolf benzine lamp is used the disease is not prevalent.

Stassen $\left(^{5}\right)$ has recently issued some interesting statistics which support this view. His results are given in the table below.

\begin{tabular}{|c|c|c|c|c|c|}
\hline \multirow[b]{2}{*}{ Mode of Lighting. } & \multicolumn{2}{|c|}{$\begin{array}{l}\text { Luminosity in } \\
\text { Heffner units. }\end{array}$} & \multicolumn{3}{|c|}{ Influence on Nystagmus. } \\
\hline & $\begin{array}{l}\text { Beginning } \\
\text { of shift. }\end{array}$ & $\begin{array}{l}\text { End oị } \\
\text { shift. }\end{array}$ & $\begin{array}{c}\text { Grave cases } \\
\text { per } 10,000 .\end{array}$ & $\begin{array}{c}\text { Serious } \\
\text { cases } \\
\text { per } 1,000 .\end{array}$ & $\begin{array}{l}\text { No. of cases } \\
\text { to \% of } \\
\text { workers on } \\
\text { day shift. }\end{array}$ \\
\hline $\begin{array}{llr}\text { Oil Safety Lamps } & . . & \ldots \\
\text { Benzine Lamps } & \ldots & \ldots \\
\text { Candles and Naked } & \text { Lamps } \\
\text { Electric Lamps } & \ldots & \ldots \\
\text { Acetylene Lamps } & \ldots & \ldots\end{array}$ & $\begin{array}{l}0.50 \\
1.01 \\
0.7 \\
1.75-2 \\
8-15\end{array}$ & $\begin{array}{r}0.28 \\
0.80 \\
0.7 \\
1 \frac{1}{2}-1 \frac{3}{4} \\
8-15\end{array}$ & $\begin{array}{r}35 \\
12 \\
0 \\
8 \\
0\end{array}$ & $\begin{array}{r}57 \\
44 \\
13 \\
12 \\
0\end{array}$ & $\begin{array}{l}31 \\
21 \\
28 \\
15 \cdot 4 \\
0\end{array}$ \\
\hline
\end{tabular}

\section{IV.-Economic Factors}

We are by this time agreed, I hope, that the illumination in the safety lamp coal mine is insufficient. Three considerations stand out-

(1) What benefits may be expected with an increased illumination ;

(2) Will these benefits justify the increased cost;

(3) Results obtained from increased illumination.

(1) Benefits to be expected.-The Departmental Committee on Lighting in Factories (1915) after a very thorough examination of evidence, supported by experimental work, came to the following conclusions :

The effects of unsatisfactory illumination are-

(A) Accidents. Increased prevalence. .

(B) Damage to eyesight and health. 
"There is a general impression that unsatisfactory lighting is, in various ways, prejudicial to health."

(c) Diminished output., Generally admitted.

If these results are found in the comparatively good illumination of factories, how much more should they be found in the admittedly bad illumination of the coal mine.

Incidence of accident and industrial disease.-Let us see first what accident and industrial disease cost the coal owners.

(A) Accidents.-The figures quoted are taken from the blue books "Statistics of Compensation," last published in 1914 for the year 1913.

In 1913, 195,387 accidents occurred in the mining industry of Great Britain. For the years 1909-1913 inclusive, the average cost of compensation per person employed was 22s. With the present 75 per cent. increase in the rate of payment this figure will be correspondingly increased. From 1909-13 the cost of compensation rose yearly, and it is probable that for 1920 the average cost per person employed will be over $£ 2$.

Official returns state that in 1919, 1,113 fatal accidents, causing 1,176 deaths, took place in the mines of Great Britain.

How many of these accidents, both trivial and fatal, might have been prevented with better illumination?

It is alleged, and quite justly alleged, that many accidents are due to carelessness on the part of the workmen, but might not increased illumination lessen the incidence of these accidents? In my official capacity I see thousands of accidents every year and I have often been struck by the history given by the men. I have often felt that so little separates the occurrence from the non-occurrence of many of the smaller accidents which mount up so in the aggregate and cause much loss of time. Quite trivial accidents lead to serious consequences. A stiff finger may throw a man out of work for months. The more serious accidents generally occur from falls of roof at the coal face or in the main roads from insufficient spragging of the loads. It is commonsense to say that, with a better light especially with a lamp that can be tilted without fear, the examination of the roof for the treacherous cracks which indicate the coming fall will be facilitated.

Out of 3,333 consecutive accidents in one mining district 3,057 occurred underground. The coal face was responsible for 52.27 per cent., the haulage roads for 45.6 per cent., and the shaft and pit bottom for the rest-2.13 per cent.

(B) Industrial disease.--In the paper read at Stoke I stated that over 6,000 men had been disabled every year since 1913 from miners' nystagmus and that the cost to the country, not to the industry, was one million pounds a year. The paper was reprinted in the leading colliery journals and was the subject of a leading article 
in one journal. No adverse criticism was made on the figures which, may then, be taken as approximately correct.

The average age at failure in my cases was 40 years. The services of able-bodied men of 40 , then, may be lost to the State when they should have twenty years of working life before them. We may say that accident and industrial disease cost the colliery proprietors two million a year and the State much more.

(C) Qutput.-If you conserve your man power by diminishing the incidence of accident and disease you will necessarily increase the output. As a direct result of increased illumination you should have an increased output.

(2) Cost of increased illumination.-A commercial proposition?

Quite apart from the moral obligation of the coal owner to alleviate the conditions under which his employees work I hold that the expense incurred in increasing the illumination is sound commercially. I am sure the colliery owners would be only too willing to introduce new installations if they were sure of obtaining a satisfactory lamp. In a discussion $\left({ }^{2}\right)$ last month on a paper on safety lamps by $\mathrm{Mr}$. James Jackson before the Lancashire Branch of the National Association of Colliery Managers, Mr. A. Miller said "A point that had struck him was that they were using the same lamps as they did 30 years ago, a fact which was no credit to the mining community generally-it was sufficient if they got a light which was good and could burn for ten hours. That was what was required, and the sooner the inventive minds in the country turned their attention in that direction, and the sooner the owners let makers know they were prepared to pay for it, because it would be one of the cheapest things they could have, the better it would be for the mining community."

The electric lamp costs from $\frac{1}{2}$ d. - 1d. a week more than the oil lamp, but the original cost is much higher.

The cost of the oil lamp is generally given at $3 \frac{1}{2} \mathrm{~d}$. per lamp per week. The cost of the electric lamp varies very much Mr. Johnson estimates the cost of the electric lamp used at the Mossfield Colliery at about $2 \frac{1}{2} \mathrm{~d}$. per lamp per week. Figures quoted by lamp manufacturers, including cost of lamp, show the cost to vary from $0.79-0.82$ of a penny per shift without current or labour. Upkeep costs may vary from 1d. per lamp per week in the first year to $3 \mathrm{~d}$. in the third year when renewals and purchase of duplicate parts are required.

I think the lamp of the future will be the electric lamp and already large numbers are being installed. One firm claims to have nearly 200,000 of its lamps in use, including installations of 12,000 and 15,000 lamps to two companies.

Results of increased illumination.-I have shown you the magnitude of the subject and you will ask if I have any figures to support 
the contention that increased illumination diminishes the incidence of disease and accident and increases output.

(1) In the open light pit nystagmus is rare, in the safety lamp pit the disease is common. I have shown that the illumination in an open light pit is five times that of a safety lamp pit. No comparison can be made between these pits from the point of view of accident.

(2) In my own district, the Mossfield Colliery Company own two pits a couple of miles apart in which the same seam is worked under exactly similar conditions. Six years ago nystagmus was equally common in both pits and the Manager, Mr. Caleb Johnson, started to introduce electric lamps into one of the pits. I went down one of the pits (Pit A) and took photometric readings six years ago and I have repeated these tests in the second pit (Pit B) last week. The readings, together with $\mathrm{Mr}$. Johnson's figures as to output, incidence of disease and accident are given in the table below :-

\begin{tabular}{cr|c|c|c|c|c}
\hline & \multicolumn{2}{|c|}{$\begin{array}{c}\text { Lamps used } \\
\text { C.P. }\end{array}$} & $\begin{array}{c}\text { Illumination } \\
\text { at coal face in } \\
\text { foot-candles. }\end{array}$ & $\begin{array}{c}\text { Cost of } \\
\text { Nystagmus } \\
\text { per ton. }\end{array}$ & $\begin{array}{c}\text { Shifts lost } \\
\text { from } \\
\text { accident. }\end{array}$ & $\begin{array}{c}\text { Output per } \\
\text { person per } \\
\text { shift. }\end{array}$ \\
\hline Pit A & $\ldots$ & Oil $\quad 0.25$ & 0.015 & ${ }_{5}^{3} \mathrm{~d}$. & 1 in 23 & 100 \\
Pit B & $\ldots$ & Electric 0.62 & 0.023 & negligible. & 1 in 54 & 105 \\
\hline
\end{tabular}

These measurements were all taken at the end of the shift in a very dusty seam.

I include some figures from South Wales, where the introduction of electric lamps has been carried,out on a large scale.

Dr. Phillips has kindly sent me the number of fresh cases of nystagmus occurring during the last five years among 10,000 colliers working for two companies. In one company oil lamps alone are used, and the yearly incidence percentage of nystagmus is 0.57 ; in the other company, nearly 50 per cent. of the lamps used are electric, and the incidence of the disease is 0.175 .

Dr. Phillips writes: "The incidence of nystagmus is undoubtedly greater where oil lamps only are used. I am also convinced that the presence of nystagmus is responsible for a large number of accidents."

Dr. Elworthy says that for the years 1909-1911 the percentage of nystagmus among underground workers was 0.71 . With improved ventilation and the introduction of over 6,000 electric lamps the incidence fell in 1919 to 0.1 per cent.

In the Ophthalmoscope, Vol. XIII, Mr. Coulter, of Newport, quotes a letter from the Manager of a group of Welsh Collieries employing 2,600 men. The letter is slightly abbreviated :

"Sir,-We had had 102 cases of nystagmus certified, but a far greater number of men have appealed to us for electric lamps. Electric lamps on á small scale were introduced June, 1912. A 
number of cases working on surface have returned to work underground with electric lamps. From experience gained we have come to conclusion: 1st, that insufficient light causes nystagmus; 2nd, that the introduction of electric lamps has enabled scores of our workmen to continue working underground; 3rd, that the use of an electric lamp is a good preventative of nystagmus."

\section{V.-Standard of Illumination Required}

Nystagmus is common in oil safety lamp pits, and rare in candle pits. If, then, we compare the light given by the oil safety lamp in general use with that of the candle, we may be able to set up a standard of minimum illumination. In the following table the value of the candle has been taken as 1 wherever possible.

\begin{tabular}{|c|c|c|c|c|}
\hline & & & Candle. & Safety Lamp. \\
\hline 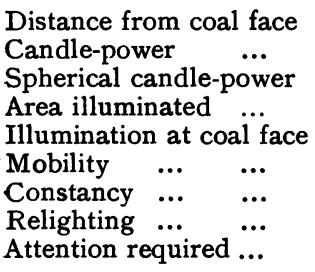 & $\begin{array}{l}\ldots \\
\ldots \\
\ldots \\
\cdots \\
\ldots \\
\cdots \\
\cdots \\
\cdots\end{array}$ & $\begin{array}{l}\ldots \\
\cdots \\
\cdots \\
\cdots \\
\cdots \\
\cdots \\
\cdots \\
\cdots\end{array}$ & $\begin{array}{c}1 \\
1 \\
1 \\
1 \\
1 \\
\text { Can be placed anywhere. } \\
\text { Remains constant. } \\
\text { Easy. } \\
\text { Nil. }\end{array}$ & $\begin{array}{c}2-6 \text { times as far. } \\
0.5 \\
0.22 \\
0.5 \\
0.2 \\
\text { Fixed. } \\
\text { May lose } 30 \% \\
\text { Difficult } \\
\text { Frequent }\end{array}$ \\
\hline
\end{tabular}

I suggest the standard to be aimed at be that of the candle pitan average illumination of one-tenth of a foot-candle-over the whole working area. A cap lamp of one candle would give a greater illumination than this, but the ordinary lamp placed at least twice as far from the face as a candle, must be of three to four candlepower to give the same result.

Last week I was able to test underground this Oldham electric lamp, which I now show you. While walking to the coal faces I wore the lamp in my belt and the whole of the travelling road was well lit up. I have never picked my way so easily in a pit. At the coal face the lamp was worn in the cap and the following measurements were taken :

$$
\begin{aligned}
& \begin{array}{llll}
\text { Candle-power ... } & \ldots & \ldots & 0.95
\end{array} \\
& \text { Drilling shot hole } \quad \ldots \quad \ldots \quad \ldots .1 \text { foot-candle* } \\
& \text { Working ratchet machine } \quad \ldots \quad 0.55 \\
& \text { Examination of roof } \ldots \quad \ldots \quad 0.25-28 \\
& \text { Holing } \\
& \begin{array}{lllll}
\text { Kneeling } & \ldots & \ldots & \ldots & 0.18
\end{array} \\
& \text { In semi-reclining position } \ldots .0 .18 \\
& \text { Full reclining position, coal } \\
& \text { undercut, } 2 \text { feet } 3 \text { inches } 0.08
\end{aligned}
$$

${ }^{*} \mathrm{~A}$ Hailwood combustion lamp placed in nearest position gave 0.02 foot-candle. 
Compare the last readings given with the average general illumination of an oil safety lamp coal face, 0.018 foot-candle, and with the results given in Table 1.

The most striking features about the lamp are the large area and uniformity of illumination and the absence of shadows. The old Japanese proverb that the darkest place is just below the candlestick fortunately remains true and the workers' eyes are consequently protected from all glare.

If the lamp is held two feet three inches from a blank wall an area 15 feet wide and ten feet high is illuminated. The weight of the lamp is $2 \frac{3}{4} \mathrm{lb}$., the lamp itself and twelve inches of cable weigh seven ounces, a small weight for men who have been used to wearing a steel hat.

Examination of the roof can be carried out very quickly and efficiently. I was very impressed with the trial and predict a great future for a lamp of this character. The advantage of taking your light with you wherever you go and always having it most advantageously placed makes the cap lamp about 6.8 times as efficient as an ordinary oil safety lamp and two to three times as efficient as the electric lamps in present day use. I suggest the lamp be given a trial in the first place in the haulage roads where the lamp has to be continually carried about, and where twenty per cent. of all oil lamps are extinguished each shift.

The miner's lamp.-The miner's lamp should be safe, foolproof, and of simple construction. It should be of substantial make and easily taken to pieces for repair. If not built to stand the rough usage it will undoubtedly receive, no repeat orders. will be obtained, and discredit will be thrown on the industry. A constant steady light for at least eight hours is required. The area illuminated should be as large as possible and few shadows should be thrown. The lamp should be easily re-lighted and require no ąttention. An easily adjustable and readily removable reflector should be fitted.

The purely technical questions of the relative advantages and disadvantages of the acid and alkaline cells, the high upkeep cost and variability of bulbs and other kindred matters I leave to the makers, but I must call attention to the poor quality of the glass. supplied, both to the oil and electric lamp manufacturers. A good light may be quite marred by the poor quality of the lamp glass.

Lamp-room organization. - Under this heading I only wish to call attention to the importance of the lamp-room, which should be the show place of the colliery and under the care of a thoroughly capable and experienced man. The proper cleaning of lamps, especially oil lamps, is of great importance and machine brushes should be fitted. Lamps cannot be cleaned by hand without undue multiplication of the staff. 
Miners' Lamp Committee.-At the present moment there is, sitting in London, a Committee to inquire into the improvement of the miners' lamp. Let us assume for the moment that they will decide that, although the lamps of the present day show great improvement, the standard reached is not sufficient for them to recommend the general introduction of any one lamp. What will they do? Will they leave the future of the lamp in the hands of manufacturers, laying down a standard to be aimed at, or will they throw the onus on the coal industry? This brings up the question of research and the advisability or otherwise of apportioning a sum of money for this end.

I hope it will be the privilege of this meeting, which Mr. Gaster has striven to make as representative as possible, after pointing out the urgent need for increased illumination in our coal mines, to indicate the methods for obtaining this end. I myself am full of hope, as the coalowners, who, as a class, have always the best interest of their employees at heart, now realise the importance of the question. I think that in this twentieth year of the twentieth century the long continued supremacy of the farthing dip will be finally ended.

\title{
REFERENCES.
}

(I) Llewellyn. A Lecture on Miners' Nystagmus given before the North Staffordshire Branch of the Institute of Mining Engineers, January, I920. Trans. Inst. Min. Eng., Vol. LVIII, part 3, p. 167-182.

(2) Llewellyn. - “" Miners' Nystagmus," 1912.

(3) Parsons. - Royal London Ophthal. Hospilal Reports, Vol. XVIII, part 3.

(4) Cridland. - Ophthalmoscope, Vol. XII, p. 727.

(5) Stassen. - "La Fatigue Visuel chez les Ouvriers Mineurs," Liège.

(6) Edridge-Green - “B.M.J." I912, Vol. I, p. I127.

(7) Elworthy.-Ophthalmoscope, Vol. X, p. 688.

(8) Dransart.-Bull. de la Soc. belg. d'Ophtal., September, I9Io.

(9) Ohm. -Arch. f. Ophthal., Vol. XCI., p. 157.

(Io) Lancaster. - Ophthalmoscope, Vol. XIII, p. 390

(I I) Vernon.-Memo. No. 21, "Health of Munition Workers' Committee."

(12) Iron and Coal Trades Review, Feb. 6, 1920, p. I74.

\section{b-ILLUMINATION IN COAL MINES-SOME OBSERVATIONS}

\author{
By H. S. Elworthy, F.R.C.S. \\ EBBW VALE, MON.
}

To illuminate coal mines satisfactorily, what is required is a safety lamp that will give sufficient light, and of a suitable quality to enable the miner to work' without getting the disease known as miners' nystagmus.

This is a disease of the nervous system, and not one of the eye only.

As mines become older, and the coal further away from the fresh air shaft, the air becomes more deoxydised, and oil lamps give less 